EGU21-14714

https://doi.org/10.5194/egusphere-egu21-14714

EGU General Assembly 2021

(c) Author(s) 2021. This work is distributed under

the Creative Commons Attribution 4.0 License.

\title{
Magnetostratigraphic dating of the Paleogene synorogenic sediments of the NE sector of the Ebro Foreland Basin (Spanish Pyrenees)
}

Charlotte Peigney ${ }^{1,2}$, Elisabet Beamud ${ }^{1,2,3}$, Òscar Gratacós ${ }^{1,2}$, Eduard Roca ${ }^{1,2}$, Alberto Sáez ${ }^{1,2}$, Luis Valero ${ }^{1,3,4}$, and Josep Anton Muñoz ${ }^{1,2}$

${ }^{1}$ Geomodels Research Institute, Universitat de Barcelona, Barcelona, Spain (c.peigney@ub.edu)

${ }^{2}$ Dpt. de Dinàmica de la Terra i de l'Oceà, Universitat de Barcelona, Barcelona, Spain

${ }^{3}$ Paleomagnetic Laboratory, CCiTUB - Geo3Bcn CSIC, Barcelona, Spain

${ }^{4}$ Département des Sciences de la Terre, Université de Genève, Geneva, Switzerland

In foreland settings at the front of active orogens, the aggradation/progradation of fluvial fans and sedimentary changes in lacustrine systems depends greatly on the tectonic activity and the derived drainage pattern changes in the hinterland. As a result of the emplacement and erosion of the South-Pyrenean thrust sheets, a system of N-S fluvial fans prograded into the Ebro foreland basin from late Eocene to Oligocene times. After the synorogenic deposition of the Priabonian (late Eocene) marine evaporites of the Cardona Fm, the Ebro Basin was characterized by internal drainage, with the fluvial fans grading to lacustrine systems at the center of the basin, which developed and migrated in response to subsidence changes. All these deposits were deformed by variably oriented salt-detached folds, evidencing the basinwards propagation of the deformation. In this work, we study the Solsona-Sanaüja fluvial fan system by means of litostratigraphy and magnetostratigraphy aiming to determine the age of the transition from fluvial fan to lacustrine systems in the NE sector of the Ebro Basin. The precise dating of this succession reveals causal relationships between tectonic and climatic processes affecting the source-to-sink system, including changes in the depositional style linked to the evolution of the Pyrenean fold and thrust belt.

Our new magnetostratigraphic study consisted in the sampling and analysis of 195 samples along a ca. $1800 \mathrm{~m}$ thick stratigraphic section of the late Eocene-Oligocene succession in the northern limb of the NW-SE oriented Sanaüja Anticline. Our results show overall Priabonian to Rupelian ages for the succession, considering an age of $36 \mathrm{Ma}$. (C16n) for the top of the Cardona Fm from previous magnetostratigraphic studies. This allows dating the end of the evaporitic sedimentation (top of the Barbastro Fm) as Priabonian and establishing a late Priabonian to early Rupelian (C13r) age for the transition from the younger lacustrine deposits (Torà Fm) to the continuous and most important fluvial fan episode of progradation in the study area. The final progradation of the fluvial fan system was coeval to a tectonically controlled reorganization of the drainage pattern of the basin responding to the emplacement of the South-Pyrenean thrust sheets. Meanwhile, smaller scale (hectometric-decametric) alternation between lacustrine and alluvial deposits was 
possibly driven by climatic changes related to orbital eccentricity cycles. The correlation and integration of these results with previous magnetostratigraphic studies in the area can help analyzing sedimentation patterns and architectural changes in the basin margins at a regional scale. 